\title{
Polarization and Depolarization Current Measurement of Polymer Added with Nano-particles of Silicon Oxide For HV Insulation
}

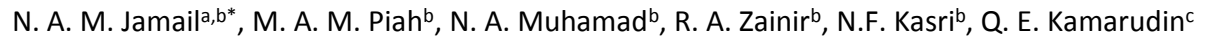 \\ ${ }^{a}$ Faculty of Electrical and Electronic Engineering, Universiti Tun Hussein Onn Malaysia \\ ${ }^{b}$ Faculty of Electrical Engineering, Universiti Teknologi Malaysia, 81310 UTM Johor Bahru, Johor, Malaysia \\ ${ }^{c}$ Faculty of Mechanical and Manufacturing Engineering, Universiti Tun Hussein Onn Malaysia \\ *Corresponding author: norakmal@uthm.edu.my
}

\section{Article history}

Received :15 February 2013

Received in revised form :

10 June 2013

Accepted :16 July 2013

\section{Graphical abstract}

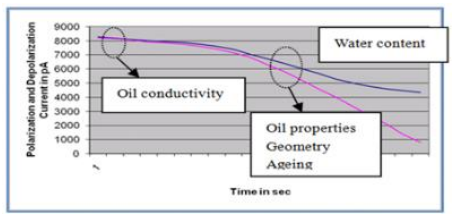

\begin{abstract}
Polymer nanocomposites materials have recently emerged as a dielectric and for electrical insulation. Polyethylene has long been used as extruded cable and HV insulation. Currently, this material has received significant attention because of its ability to enhance electrical insulation properties by addition of nano-filler. Polarization and Depolarization Current (PDC) measurement is an efficient and effective diagnostic technique based on time domain measurement for evaluating and condition monitoring of polymer nanocomopsite for HV insulation. Electrical conduction for polymer nanocomposites has been used widely as a tool to monitor the dielectric behaviour. This paper focuses on application of Polarization and Depolarization Current (PDC) testing method to evaluate and determine the performance of LLDPE nanocomposite for high voltage insulating material. The experiment was conducted to find PDC pattern of the material when added with nano-filler (silicon oxide) as well as to find its conductivity values at different percentage of nano- filler. PDC values and DC conductivity exhibits significant reduction with addition of nano-filler at different \%wt of concentration. This was due to the decrease of initiation probability of short circuit treeing in the insulation. The PDC result shows that addition with certain percentage of nano-filler into the LLDPE based material could improve HV insulation properties of the material.
\end{abstract}

Keywords: LLDPE nanocomposite; polarization current; depolarization current; DC conductivity

\begin{abstract}
Abstrak
Bahan-bahan Polimer nanokomposit baru-baru ini muncul sebagai dielektrik dan penebat elektrik. Polyethylene telah lama digunakan sebagai kabel utama dan penebatan HV. Pada masa ini, bahan ini telah mendapat perhatian penting kerana keupayaannya untuk meningkatkan sifat-sifat penebat elektrik dengan penambahan pengisi nano itu. Polarisasi dan depolarization semasa pengukuran (PDC) adalah satu teknik diagnostik yang cekap dan berkesan berdasarkan masa ukuran domain untuk menilai dan memantau keadaan nanokomposit polimer untuk penebatan HV. Pengaliran elektrik untuk polimer nanokomposit telah digunakan secara meluas sebagai alat untuk memantau tingkah laku dielektrik. Kertas kerja ini memberi tumpuan terhadap aplikasi polarisasi dan depolarization Semasa kaedah ujian (PDC) untuk menilai dan menentukan prestasi komposit nano LLDPE untuk bahan penebat voltan tinggi. Eksperimen telah dijalankan untuk mencari corak PDC bahan yang apabila ditambah dengan nano-pengisi (silikon oksida) serta untuk mencari nilai-nilai kekonduksian pada peratusan yang berbeza nano pengisi. Nilai PDC dan DC kekonduksian mempamerkan pengurangan ketara dengan penambahan nano pengisi yang berbeza pada \% wt. Ini adalah disebabkan oleh penurunan kebarangkalian permulaan litar pintas pokok dalam penebat. Keputusan PDC menunjukkan bahawa dengan penambahan bahan sampingan dengan peratusan tertentu nano pengisi ke dalam bahan berasaskan LLDPE boleh meningkatkan ciri-ciri penebat HV bahan
\end{abstract}

Kata kunci: Komposit nano LLDPE; polarisasi semasa; depolarization semasa; kekonduksian DC

\subsection{INTRODUCTION}

The oriented structure of polymers has been extensively investigated owing to its enhancement in many properties. Polymer composites are important commercial materials with various applications. As known, polymers filled with nanoscale fillers are recognized as polymer nanocomposites. Apparently, with addition of nanoscale fillers into polymers, robust materials can potentially be produced due to the synergistic effects (cooperating for enhanced effects) arising from the blending 
process[1]. Nano-silicone oxide $\left(\mathrm{SiO}_{2}\right)$ with huge surface area is widely used in polyolefin composites. Its application is now mainly focused on the improvement of mechanical and electrical properties [2-4]. Among all non-destructive monitoring techniques, the Polarization and Depolarization Current (PDC) measurement is gaining popularity due to its ability to assess the conductivity of $\mathrm{HV}$ insulations within the initial periods after a DC step voltage application. PDC analysis can easily identify whether the cause of insulation failure is due to conduction such as degradation or ageing process caused by temperature effects. The dielectric properties of an insulating material change with moisture, ageing and contamination[5]. The PDC patterns of mineral oil, biodegradable oil and paper as transformers insulation have been studied by many researchers such as [5-7] . But until now, there are no investigations on PDC done for LLDPE/NR nanocomposite as a new insulation. Study on the PDC pattern of polymer nanocomposite is required as an increasing number of power utilities nowadays choose polymer nanocomposite as a new insulation due to its unique properties. This paper studied the PDC pattern of LLDPE-NR at different percentage amount of $\mathrm{SiO}_{2}$. In this paper, PDC technique is used to monitor the conductivity variations due to its polarization and depolarization current values. Different types of nano-filler give different variations.

\subsection{SAMPLE AND MATERIAL PREPARATION}

LLDPE used in this study is a commercial linear low density polyethylene from Titan Chemical, Malaysia. It has a density of $0.918 \mathrm{~g} / \mathrm{cm}^{3}$, a melt index of $0.25 \mathrm{~g} / \mathrm{min}$. Nanoparticle of silicon oxide is made from China with a particle size of about $<50 \mathrm{~nm}$ was used as filler. This nano scale filler has a nearly spherical shape with a specific surface area of about $100 \mathrm{~m}^{2} / \mathrm{g}$. The filler was dried before use. Natural rubber grade SMR CV 60 supplied by Taiko Plantations Sdn Bhd was used for blending and mixing with LLDPE and nano-filler. Polyethylene nanocomposites were prepared by melt mixing at $165^{\circ} \mathrm{C}$ using a Brabender type model 835201.041 mixer with chamber size of $50 \mathrm{~cm}^{3}$. The mixer has a high shear force and the screw speed was controlled at $35 \mathrm{rpm}$ with the mixing time of 2 minutes. The polymer nanocomposites were finally prepared into square shape of $10 \mathrm{~cm} \times 10 \mathrm{~cm}$ with the thickness of $3 \mathrm{~mm}$ by hot melt pressing at 1 tone pressure at $170^{0}$ $\mathrm{C}$ for 10 minutes. Four types of polyethylene nanocomposite square shaped with a diamension of $10 \mathrm{~cm} \times 10 \mathrm{~cm}$ were prepared with concentrations of nano-filler of $0,1,3,5$ and 7 wt \%, respectively. All the preparation for the test sample and material are shows in Table 1.

Table 1 Compound formulations and designation

\begin{tabular}{|c|c|c|c|c|}
\hline \multirow{3}{*}{ Test Sample } & \multicolumn{3}{|c|}{ Constituents composition \%wt } & \multirow{2}{*}{} \\
\cline { 2 - 5 } & LLDPE & $\begin{array}{c}\text { Natural Rubber } \\
\text { (SMR CV 60) }\end{array}$ & Nanofiller & Designation \\
\hline unfilled LLDPE & 100 & 0 & 0 & $\mathrm{~A}$ \\
\hline $\begin{array}{c}\text { LLDPE + Natural } \\
\text { Rubber }\end{array}$ & 80 & 20 & 0 & $\mathrm{~A} 0$ \\
\hline \multirow{3}{*}{$\begin{array}{c}\text { LLDPE + Natural } \\
\text { Rubber + SiO2 }\end{array}$} & 80 & 20 & 1 & $\mathrm{~A} 1$ \\
\cline { 2 - 5 } & 80 & 20 & 3 & $\mathrm{~A} 3$ \\
\cline { 2 - 5 } & 80 & 20 & 5 & $\mathrm{~A} 5$ \\
\hline
\end{tabular}

\subsection{PDC THEORY AND CONCEPT}

\subsection{Insulation Conductivity Concept}

By examination of the PDC curves, parameters such as conductivity and moisture content in the insulation can be estimated. Figure 1 shows example of PDC curve in $\mathrm{dB}$ plot. The figure shows the oil conductivity, oil properties, geometry, ageing and water content influence on the PDC-Curve[8]. Based on the figure the conductivity of the insulation can be measured from the front tail of the PDC curve. Value of conductivity affects the polarization current mainly in a time range $t<100$ s. Higher conductivity leads to a higher current value.

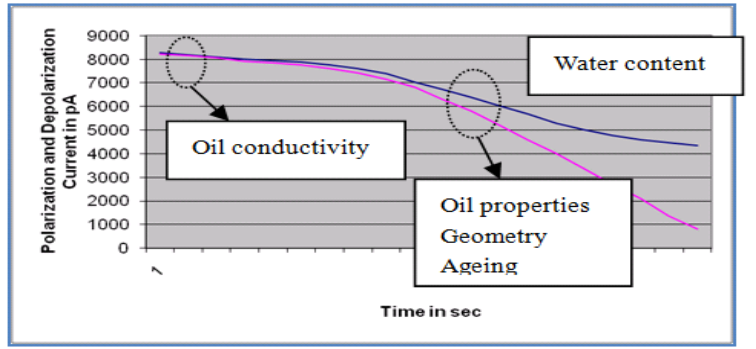

Figure 1 Oil conductivity, oil properties, geometry, ageing and water content influence on the PDC-Curves [8]

The estimation of the conductivity for HV insulation under polarization and depolarization test result can be expressed from the PDC value $[5,6,9-11]$. The test object can be a single dielectric material or an arrangement of several dielectric materials in series or in parallel. For more than one dielectric material, $\sigma, \varepsilon_{\mathrm{r}}$ and $f(t)$ represent the composite conductivity, relative permittivity and dielectric response function of this heterogeneous test object respectively. Assuming that the test object is totally discharged and that a step voltage is applied with the following characteristics [6]:

$$
U(t)=\left\{\begin{array}{cc}
0 & t<0 \\
U_{o} & 0 \leq x \leq t_{c} \\
0 & t>t_{c}
\end{array}\right.
$$

This will give zero current for times before $t=0$, and socalled polarization currents for times $0 \leq t \leq 0$. The polarization current is built up in two parts, one part is related to the conductivity of the test object and the other is related to the activation of the different polarization processes within the test object. The polarization (charging) current through the object can thus be expressed as $[5,6,9-11]$ :

$$
i_{p}(t)=c_{o} u_{o}\left[\frac{\sigma}{\varepsilon_{r}}+f(t)\right]
$$

Once the step voltage is replaced by a short circuit, a depolarization current is built up. The magnitude of the depolarization current is expressed as [5, 6, 9-11]:

$$
i_{d}(t)=c_{o} u_{o}\left[f(t)-f\left(t+t_{c}\right]\right.
$$

where $t$ is the time during which the voltage has been applied to the test object.

From the measurements of polarization and depolarization currents, it is possible to estimate the dc conductivity $\sigma$, of the test object. If the test object is charged for a sufficiently long time so 
that $f\left(t+t_{c}\right) \cong 0$, equation (2) and equation (3) can be combined to express the dc conductivity of the composite dielectric as [5, 6, 9-11]

$$
\sigma \approx \frac{\epsilon_{\mathrm{o}}}{\mathrm{C}_{\mathrm{o}} \mathrm{U}_{\mathrm{o}}}\left[\mathrm{i}_{\mathrm{p}}(\mathrm{t})-\mathrm{i}_{\mathrm{d}}(\mathrm{t})\right]
$$

\subsection{PDC Measurement Technique}

The polarization currents measurement is performed by applying a dc voltage step on the dielectric materials and depolarization current is measured by removing the dc voltage source incorporating with a switch which turn on to short circuit at the under tested objects. The dc voltage applied was $1000 \mathrm{~V}$ for about 10,000 seconds for polarization and depolarization time. The principles of PDC measurement is shown in Figure 2.

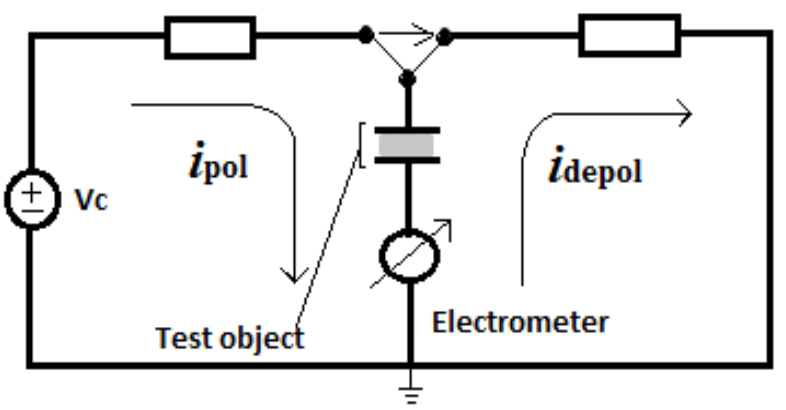

Figure 2 Principle of test arrangement for PDC measurement

\subsection{PDC MEASUREMENT RESULTS AND DISCUSSION}

\subsection{Polarization and Depolarization Current Analysis}

The results for polarization and depolarization currents measured for samples A and A0 are shown in Figure 3 and Figure 4. As seen in the figures, A0 has lower polarization and depolarization current values than sample A. It found that the compound of $80 \%$ LLDPE and $20 \%$ natural rubber can improve the resistivity of the material.

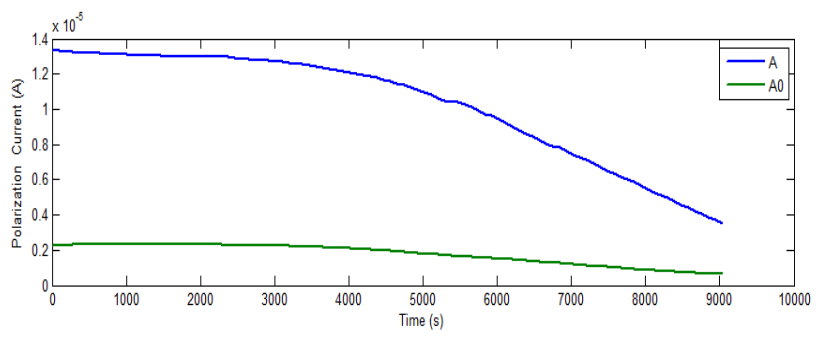

Figure 3 Polarization current values for sample A and A0

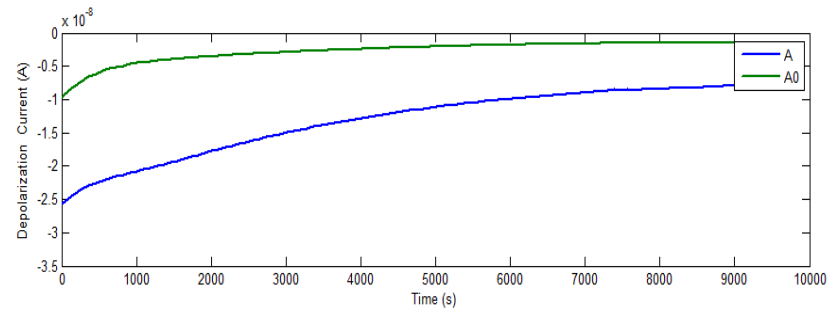

Figure 4 Depolarization current values for sample A and A0
The results for polarization and depolarization currents measured for samples A1-A5 are shown in Figure 5 and Figure 6. Based on the plotted graph, sample A5 has the lowest polarization and depolarization current value. This also means that this sample has the lower conductivity level compared with the others group A samples. Sample A5 that contained $5 \mathrm{wt} \%$ of $\mathrm{SiO}_{2}$, shows the higher resistivity based on the lowest polarization current recorded. It is found that the amount of $5 \%$ wt of $\mathrm{SiO}_{2}$ will give the optimum composition for LLDPE-NR polymer in order to increase the resistivity of the material. The interaction between the matrix and the fillers is related to the chemical properties of the filler surface and the interfacial area between the matrix and the fillers.

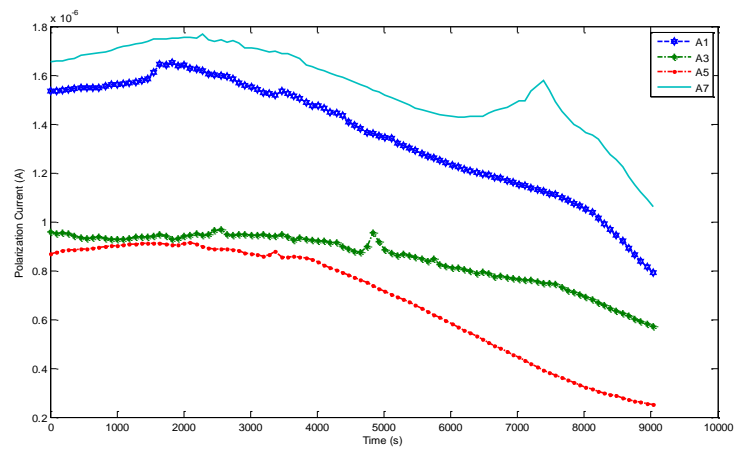

Figure 5 Polarization current values for sample A1, A3, A5 and A7

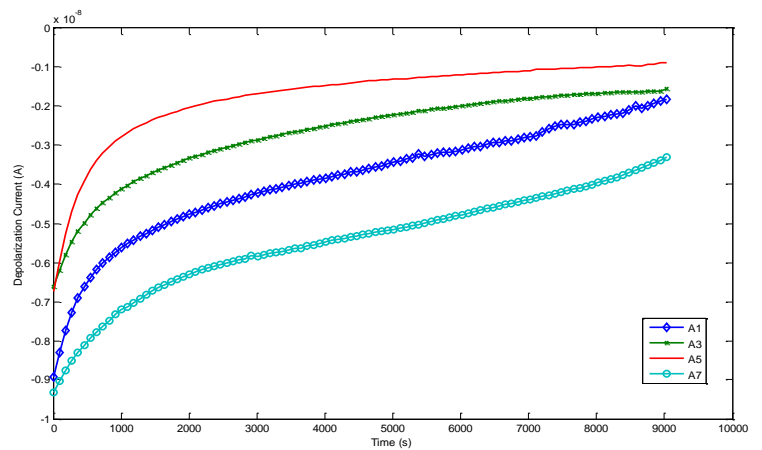

Figure 6 Depolarization current values for sample A1, A3, A5 and A7

\subsection{Conductivity Variation Analysis}

Polarization and depolarization current measurement enables estimation to be made on the condition (moisture and ageing) of insulation with different conductivities. From Equation (4), it proves that conductivity of the insulation is influenced by polarization and depolarization current values. Figure 7 shows the conductivity variations for unfilled LLDPE and LLDPE-NR samples. Based on the plotted graph, LLDPE-NR sample has lower conductivity as compared with pure LLDPE sample. 


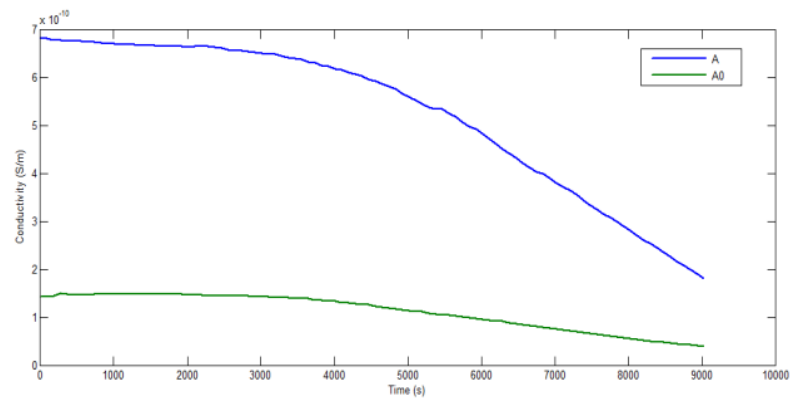

Figure 7 Conductivity variations for A and A0

Figure 8 shows the conductivity variations for LLDPE$\mathrm{NR} / \mathrm{SiO}_{2}$ samples at different amount of nano-filler. As seen in the figure, the conductivity of LLDPE-NR/SiO 2 is decreased as the percentage adding $\mathrm{SiO}_{2}$ nano-filler increased from $1 \%$ wt to 5 $\%$ wt. However, when the percentage of nano-filler was further increased to $7 \% \mathrm{wt}$, the conductivity becomes higher than the sample with $3 \%$ wt and $5 \%$ wt. Sample with amount of $5 \% \mathrm{wt}$ $\mathrm{SiO}_{2}$ nano-filler becomes the best sample as it has a lowest conductivity compared to others in the same group.

The higher value of conductivity of A7 as compared to A5 indicates that the $\mathrm{SiO}_{2}$ nano-filler more than $5 \%$ wt has reversed the improvement on the dielectric properties of LLDPE. This is because the filler will agglomerate in both composite samples. Those observed in the sample are clearly larger size of filler for higher \%wt of nano-filler. Addition of $\mathrm{SiO}_{2} 5 \%$ wt as filler will do more improvement of dielectric properties and lower conductivity level as compared to other composition. The properties of $\mathrm{SiO}_{2}$ nano-filler as dielectric filler tends to improve the dielectric properties as a good insulator.

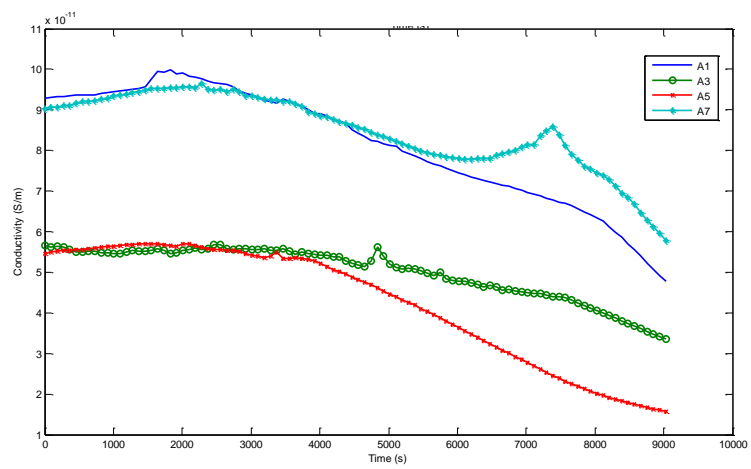

Figure 8 Conductivity variations for sample LLDPE-NR/SiO $\mathrm{S}_{2}$ at different amount of nanofiller

\subsection{CONCLUSION}

Diffferent types of nano-filler and percentage of concentration will give different values of polarization and depolarization current values. It can be observed, changes in insulation polarization and depolarization current values tend to affect the value of conductivity. From the results, it can be concluded that adding nano particles into LLDPE nanocomposite can reduce the PDC values. However, different amount of nano-fillers will give different results. By reducing the conductivity to the lowest value, it can be known that a small amount of nano-fillers is separated inside the dielectric with a certain wide distance, which can be known as 'extra traps' for the dielectric, and therefore improve the insulation property. However, if more nano particles added into the LLDPE, for example 5\% wt has showed a better insulation property than the pure sample with the higher conductivity compared to the samples of $1 \%$ and $3 \%$ wt. This is because that some of the nano-fillers are too closed to each other, and each nano particle has an interaction zone around it that resulting some overlap of interaction zones. For higher contents of nano-filler, the probability of interaction zones overlap is getting higher, and therefore, the nano particles may aligned together which helps the charges moving across the dielectric. The results from PDC measurements can be used to determine the insulating condition properties of LLDPE nanocomposite. Higher values of polarization and depolarization currents contribute to higher conductivity of the materials. The trends of the conductivity variation were found to be dependent on the polarization and depolarization currents values.

\section{Acknowledgement}

The authors gratefully acknowledge the Malaysia Ministry of Higher Education, Universiti Teknologi Malaysia under grant (Qj130000.7123.00J09 and R.J130000.7823.4F097) and Universiti Tun Hussein Onn Malaysia for financial support, TNB Research Sdn Bhd for equipment support and Taiko Plantation Sdn Bhd as a supplier of Natural Rubber.

\section{References}

[1] B. Jongsomjit, J. Panpranot, P. Praserthdam. 2007. Materials Letters. 61: $1376-1379$.

[2] D. Xiaobing, Y. Yi, L. Zhe. L.Xuguang. 2007. IEEE International Conference on Solid Dielectrics. 377-380.

[3] Y. Huang, S. Jiang, L. Wu, Y. Hua. 2004. Polymer Testing. 23: 9-15.

[4] J.-S. Jang, J. Varischetti, G. W. Lee, J. Suhr. Composites Part A: Applied Science and Manufacturing. 42: 98-103.

[5] N. A. Muhamad, B. T. Phung, T. R. Blackburn, K. X. Lai. 2009. Power Engineering Conference, AUPEC 2009. Australasian Universities. 1-6.

[6] T. K. Saha, P. Purkait. 2004. IEEE Transactions on Dielectrics and Electrical Insulation. 11: 144-154.

[7] T. Gradnik M..Babuder, M. Koncan-Gradnik. 2008. ICDL 2008. IEEE International Conference on Dielectric Liquids.1-4.E. Astorino, J. B. Peri, R. J. Willey, G. Busca. 1996. J. Catal. 157: 482.

[8] H. A. P. Silva, W. Bassi, A. C. T. Diogo. 2004. Transmission and Distribution Conference and Exposition: Latin America, 2004 IEEE/PES. 611-616.

[9] T. K. Saha, M. K. Pradhan J. H.Yew. 2007. IEEE,Power Engineering Society General Meeting. 1-7.

[10] C. Ekanayake, T. K. Saha, H.Ma, D.Allan. 2010. IEEE Power and Energy Society General Meeting. 1-8.

[11] T. K. Saha, P. Purkait. 2004. IEEE Transactions on Power Delivery. 19: $127-1134$. 